Vesna S. Trifunovic

\title{
MIGRATION PROCESSES AND DEMOGRAPHIC STRUCTURE IN THE EASTERN BORDERLANDS OF THE REPUBLIC OF SERBIA*
}

University of Kragujevac, Faculty of Pedagogical Sciences, Jagodina, Department of Humanities, 14, M. Mijalković, Jagodina, 35 000, Republic of Serbia

dimitrije95@ptt.rs

\begin{abstract}
Throughout the $20^{\text {th }}$ century until today, Serbian society has been faced with the consequences of the lack of the development policy that would create a context of equal conditions for stronger economic, social and cultural development of different regions of the Republic of Serbia. Some of the effects of such a development policy at the beginning of the $21^{\text {st }}$ century are strong migration processes that «drain» the young working population, particularly from the eastern borderlands, from the country. Migrations «associated» with decades of low birth rates trend lead to the quiet disappearance of the population in border municipalities such as Kladovo and the culture they are holding.

The paper highlights the importance of creating a development policy that would rehabilitate the consequences of decades of regional disparities in the development of Serbia. The creators of the so-called contemporary Serbian society, if they intend to offer sustainable strategies, in addition to economic, social, cultural, ecological and other discourse, must include the demographic one. Each of these discourses has its important role in the overall development of the society. However, the unfavorable demographic structure can stop it.

The paper used the analytical-descriptive method.
\end{abstract}

Key words: population; migrations; demographic changes; east borderlands; the Republic of Serbia.

Трифунович B.C.

МИГРАЦИОННЫЕ ПРОЦЕССЫ И ДЕМОГРАФИЧЕСКАЯ СТРУКТУРА ВОСТОЧНОГО ПРИГРАНИЧЬЯ РЕСПУБЛИКИ СЕРБИИ

\author{
Университет г. Крагуевац, Факультет педагогических наук г. Ягодина, М. Мијалковича 14, \\ Јагодина, 35 000, Республика Сербия \\ dimitrije95@ptt.rs)
}

\begin{abstract}
Аннотация. На протяжении всего XX века и до сегодняшнего дня, сербское общество сталкивается с последствиями отсутствия политики в области развития, которая бы создала контекст равных условий для более сильного экономического, социального и культурного развития различных регионов Республики Сербии. Некоторыми эффектами последствий такой политики в области развития начала XXI века являются сильные миграционные процессы, которые «отводят» молодое работающее население из страны, особенно из районов восточного приграничья. Миграционные тенденции, в сочетании с десятилетиями низкой стопы рождаемости, приводят к тихому исчезновению не только населения в приграничных муниципалитетах, таких как Кладово, но и культуры, чьими носителями эти жители являются.

В работе подчеркивается важность создания политики развития, которая бы реабилитировала последствия десятилетий региональных различий в развитии Сербии. Если разработчики так называемого развития современного сербского общества намерены предложить устойчивую стратегию, то они должны, наряду с экономическим, социальным, культурным, экологическим и другими дискурсами, включить и
\end{abstract}

\footnotetext{
${ }^{*}$ Prepared as a part of the project Sustainability of the Identity of Serbs and National Minorities in the Border Municipalities of Eastern and Southeastern Serbia (179013), conducted at the University of Niš - Faculty of Mechanical Engineering, and supported by the Ministry of Science and Technological Development of the Republic of Serbia.
} 
демографический дискурс. Каждый из этих дискурсов имеет свою важную роль в общем развитии общества, однако, неблагоприятная демографическая структура может это развитие приостановить.

В работе используется аналитическо-описательный метод.

Ключевые слова: население; миграционные процессы; демографические изменения; восточное приграничье; Республика Сербия.

\section{Introduction}

The movement and the development of a population are influenced by the following factors: (a) natural movement and population renewal i.e. natural growth, and (b) migrations (immigrations and emigrations). Term migration means the spatial mobility of the population. Migration (lat. migratio) relates to movement, trek. Traditionally, the term referred to the emigration, and today to long-term work and stay in the countries more developed than the country of origin of migrants. United Nations consider migrations as the forms of spatial mobility between two geographical locations, as a permanent change of residence, while in the local professional and scientific literature, migration indicates any change of residence, regardless of the duration and distance. It is believed that every act of free migration is the result of individual decisions that form two large groups of factors: (1) pull factors which include better employment opportunities, the possibility of gaining higher wages, benefits provided by the environment and living conditions, the lure of new or different activities etc. (2) push factors which include declining of natural resources or their prices, job loss, repressive discriminatory treatment, alienation from the community, etc. [1].

Migration movements occur due to the geographical imbalances in the distribution of natural resources, physical and human capital, institutions, traditions and cultural conditions which cause an uneven pace of economic development; the movement of people is also encouraged by the movement of capital and services, or their concentration in a certain area [2]. Migrations may vary based on different criteria: according to the criterion of state borders we differ external and internal migration; according to the criterion of time we differ final and temporary migration; according to the cause we differ economic and non-economic migrations; according to the willingness we differ voluntary and involuntary migration, etc.

About external migration we can speak from different perspectives; however, here we will mention two with positive connotations: (a) the perspective of migrants themselves who benefit in social and economic terms - earn more, their quality of life has improved; (b) the perspective of the country of origin of migrants - migrants bring foreign currency remittances and reduce unemployment, and to make these effects long-term, government activity in premigration, migration and post-migration phase is essential [3].

Migration has a huge impact on the demographic, social and economic structure of the country of origin of migrants: migrants are leaving their jobs, property, state (are in need of permanent abandonment of the country of origin), and consciously develop a life strategy with a better perspective by investing their own resources, and using the provided business opportunities they enhance their material position. The realization of a personal dream of migrants, from the standpoint of the country of origin of migrants, signifies a loss of human resources, the creative potential of newly created values, taxes ... Countries of origin of migrants, such as Serbia, which, in large waves in recent history since the seventies of the last century, has been abandoned by large groups of young, fertile, economically active population, go through different stages of demographic transition. Its outcomes are depopulation, lower birth rates, aging of the population. These negative demographic processes cause a series of negative economic effects and reduce the capacity of the total society to «conquer» the civilizationally reached quality of life.

Decades-long uneven economic development as a result of asymmetric development policy of the Serbian society that provided Belgrade and municipalities in the north of the country with a stronger economic growth has led to the overall social and economic backwardness of border municipalities in the southeast and east. Borderland eastern and southeastern Serbia municipalities are not recognized as potentials in post-development strategies: existing development resources are destroyed (agricultural, industrial, tourist) and, at the same time, there has been no new investment Borderlands have become synonymous with the periphery. Periphery that is becoming poorer, and with the outflow of the population. Economically stronger centers attract the active working population from the eastern border municipalities such as Kladovo (so called Ključ region). Despite the policy of European and other developed countries towards 
migrants, and especially asylum seekers, which is oriented towards programs for readmission due to the attitude of the local population, the rise in xenophobia, changes in the labor market - the population that migrates from Ključ region has developed a special «immigration policy». With the first wave of migrants, after the initial phase of their integration into the labor market, the dependent mobility of their relatives and partners has led to the expansion of migrant families i.e. to the reunification of families. The second and third generation of migrants, born and brought up in the new sociocultural environment, often does not feel the connection with the homeland of their parents and ancestors. It builds its identity on the acceptance of values and belonging to socio-cultural milieus of the «new» homeland, thus making the return to the country of origin almost impossible.

Migration processes, associated with a variety of other demographic processes, lead to the disappearance of Kladovo population: the names of settlements in which lonely houses await their owners foreign workers stretch along the Danube coast. The houses are large and made of expensive material, luxurious, however without people.

\section{Method}

The subject of this paper is to study migration and demographic structure of the population in the eastern municipality border of the Republic of Serbia, Kladovo.

The aim of the research is to determine (a) whether there are migratory movements of Kladovo population, (b) the basic characteristics of the demographic structure of the population in the eastern border municipality of Kladovo.

The tasks of the research are: (1) To determine the presence and the main characteristics of migration processes in the municipality of Kladovo, (2) to provide an insight into the statistics that follows the changes in the number of the total population, their distribution by settlements and numerical relationship among different age groups of the population.

Main hypothesis: A large percentage of the population in the municipality of Kladovo participates in the so-called external migration flows, crosses the border in search of «a better life».

Specific hypothesis: In the municipality of Kladovo, the total population is dominated by aging population.

The paper used the analysis of secondary structure (data obtained by regular censuses, reference literature dealing with migrations and demographic structure), as well as a descriptive method.

\section{Migration processes in the municipality of Kladovo}

The municipality of Kladovo is the «last point» in the east towards Romania. This border area or «peripheral system laid to the border» [4] is a separate physical-geographical and functional territorial integrity, which has a specific economic, cultural but also strategic importance. The border region of the municipality of Kladovo is located in Bor District, consisting of 23 settlements and 6 villages, of which 18 settlements are located along the coast of the Danube. These are the following settlements: Brza Palanka, Vajuga, Velesnica, Velika Vrbica, Velika Kamenica, Grabovica, Davidovac, Kladovo, Kladušnica, Korbovo, Kastel, Kupusište, Ljubičevac, Mala Vrbica, Manastirica, Milutinovac, Novi Sip, Petrovo Selo, Podvrška, Reka, Rečica, Rtkovo, Tekija. Kladovo is a town, Brza Palanka and Tekija have some characteristics of a small town, and other cities have the characteristics of rural settlements.

From Serbia to the world, one could also go from Kladovo pier, and Kladovo can be reached from other parts of Serbia by different paths. There are three main routes that connect Kladovo with Serbia hinterland: (a) from Belgrade $(260 \mathrm{~km})$ through Požarevac and Donji Milanovac, down the Danube by Đerdap highway; (b) from Paraćin $(200 \mathrm{~km})$, the connection with highway Belgrade-Niš, over the mountain saddle of Čestobrodica, Zaječar and Negotin; (c) from Niš (about $200 \mathrm{~km}$ ), over the mountain saddle of Tresibaba, Knjaževac, Zaječar and Negotin [5].

Although the border one, this area is characterized by a high degree of ethnic homogeneity: in the total population there are over 89,9\% (17 673), of Serbs, but there are also features of multi-ethnicity primarily due to the presence of Vlachs (788) in the total population and in a much lower percentage the presence of other ethnicities Romanians (156), Roma (36) and others. Ordinary people living in Kladovo region live in the same way, regardless of ethnicity: a lifestyle that is imposed by an economically deprived area and an area struggling with disastrous consequences of aging and depopulation [6].

In the municipality of Kladovo there is the small town (urban settlement) of Kladovo, which is one of the older cities in the Danube region. According to historical sources, the emergence of the village is connected to the civil war camp built by the Romans on the Danube border, called Zanes. Later, at its foundation, the Slavs built a settlement Novi Grad, only to have its Slovenian population suppressed by 
the construction of Turkish fortress Fetislam. Kladovo name is mentioned for the first time in an Austrian military document from 1596, and the oldest written information about Kladovo includes a description of the town that is recorded in his travelogue by Turkish geographer and travel writer E. Çelebi [5].

Kladovo is a small town on the bank of the Danube, which does not offer its residents great opportunities; visitors from other areas are a sporadic occurrence and but for the various national teams (volleyball, athletes) that perform part of the sports preparations here - it would be a forgotten border town. Formerly, in the time of Yugoslavia, there was a large shipyard, which has since the introduction of sanctions by the United Nations at the beginning of the nineties stagnated bringing to a halt of the economic and social development throughout Kladovo border area (today this industrial complex is foreign-owned, Romanian, and is a part of the continent Rhein Donau Yard). In the Kingdom of Yugoslavia, to the construction of hydropower plant «Đerdap» in the socialist period of development,
Kladovo was also known for world famous Kladovo caviar, which was prepared according to the old «recipe» that was brought to this area by a Russian family fled after the October Revolution. Sturgeons no longer spawn in coast of Kladovo, Kladovo caviar has no longer been served in European restaurants, hydropower plants sank old habits and customs, and economic trends in the Serbian society in recent decades have spilled over young economically active population outside the borders of the municipality of Kladovo abroad - to developed Western European societies.

According to the census of population, households and dwellings in the Republic of Serbia in 2011 and preliminary first results, in the Bor District, where Kladovo municipality is located, a constantly present downward trend in the total population is noticeable. In the period between the two censuses (2002-2011) in the Bor District, there was an absolute decline in the number of inhabitants by 22703 inhabitants. Kladovo municipality has also recorded a decline in the population by 2978 inhabitants (see Table 1).

The total population according to the census of 2011 and 2002

Table 1

Таблица 1

Общая численность населения по данным переписи 2011 и 2002 года

\section{1. Укупно пописана лица, укупан број становника према Пописима 2011. и 2002. и укупан број домаћинст ав а и станов а (наставак)}

Total enum erated persons, total number of population according to the Censuses 2011 and 2002 and total number of hous eholds and dwellings (continued)

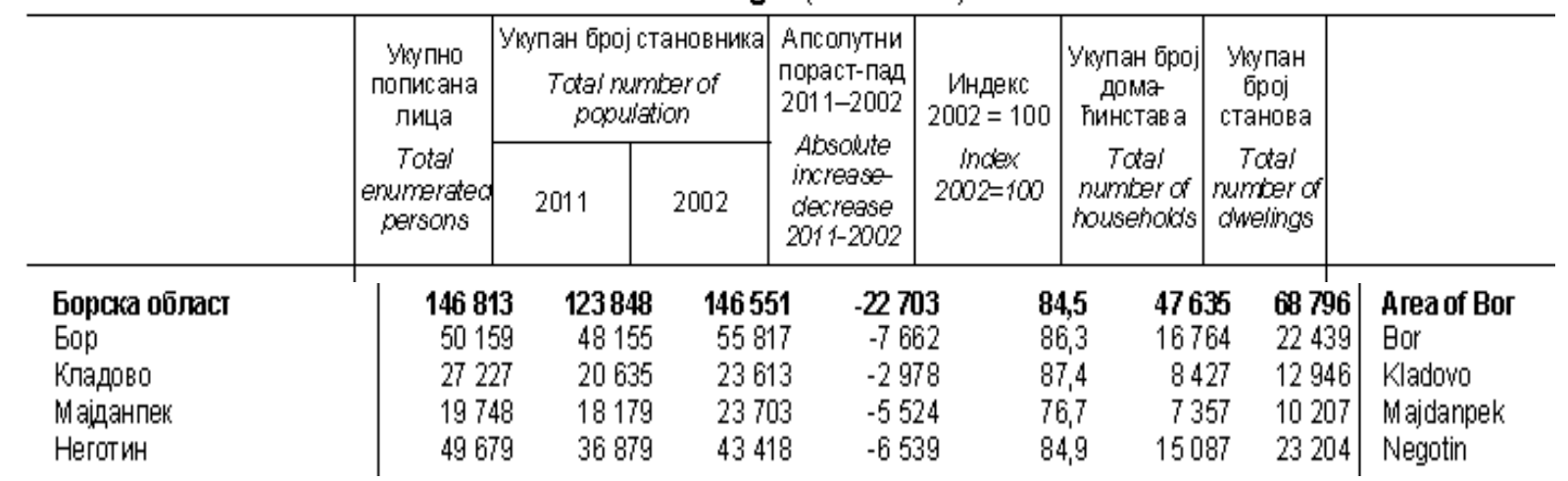

Source: Census of Population, Households and Dwellings in the Republic of Serbia - first results, Belgrade: Republic Institute for Statistics, 2011.

Data obtained from the 2011 Census show that the total number of listed persons within the territory of the border region of Kladovo is 27227 , and the total population is 20635 inhabitants - 6534 people migrated to change their place of permanent residence (the vast majority is living and working abroad).

A comparative population overview from 1948 to 2002 [7] shows that the number of people, taking into account differences in methodologies of previous censuses and the 2002 census, in the municipality of Kladovo increased in the period after the Second World War to the beginning of the nineties (Table 2). 
Сравнительный обзор численности населения в муниципалитете Кладово

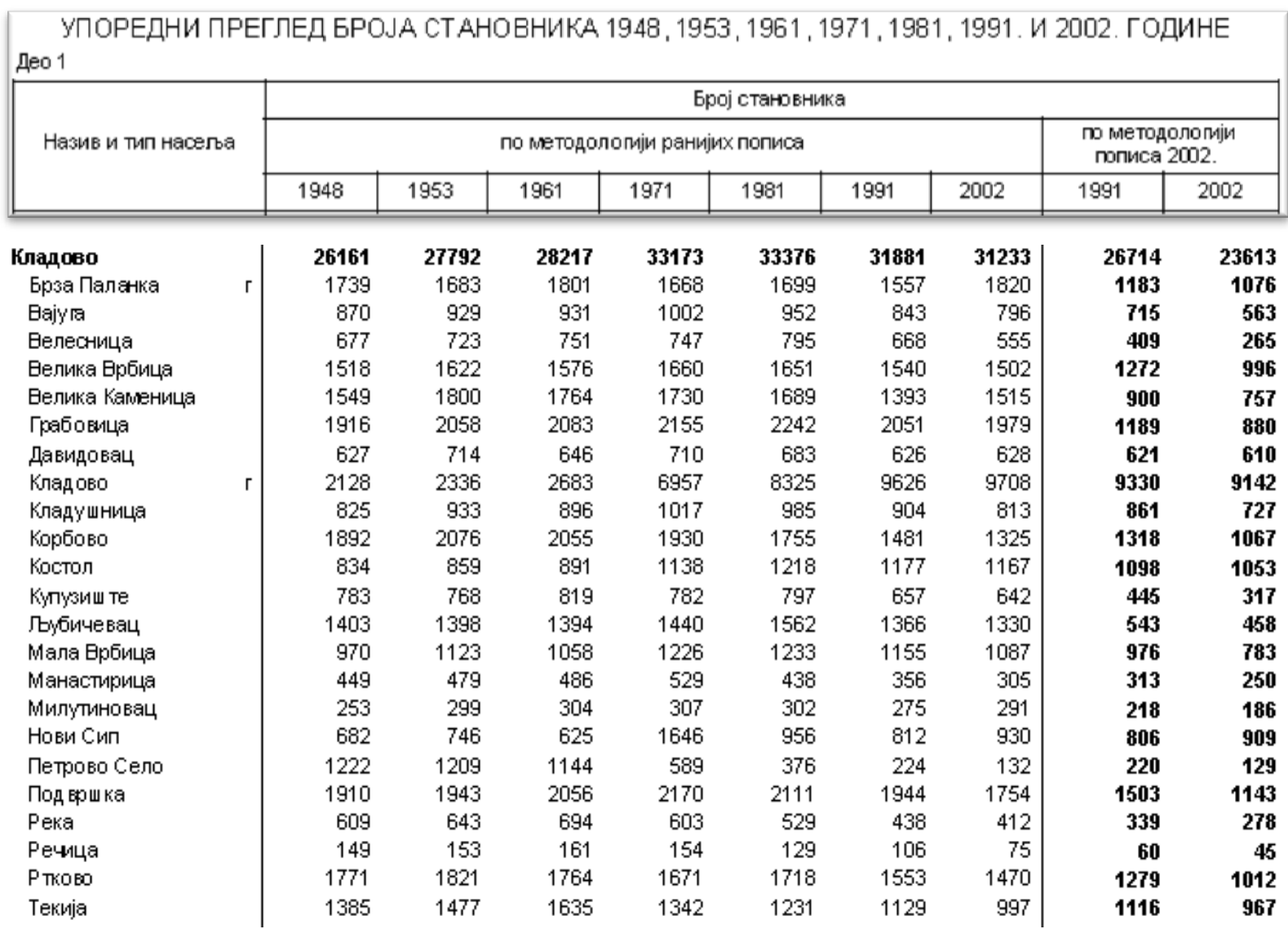

Source: Comparative population overview in 1948, 1953.1961, 1971, 1981, 1991 and 2002. Data by settlements. Belgrade: Republic Institute for Statistics, 2004.

According to the data in Table 2, the population was the highest in the period between 1961 and 1981, i.e. during the period when hydroelectric power plant «Djerdap» was being built and when the shipyard was at full capacity. In the period between 1991 and 2011 there was a significant decrease in the percentage of the total population in the municipality of Kladovo from 26,714 people who lived in Kladovo in 1991, over 23,613 people who lived in this area in 2002, we came to a figure of 20635 inhabitants [8] living in the municipality of Kladovo today.

Data from the 2011 Census show, both for the town of Kladovo and villages in the municipality of Kladovo, that a large number of residents is affected by external migratory movements: there is a big difference between the total number of listed people and the total population in these areas.
The population of 23 Kladovo settlement is distributed as follows: (1) in the main town of Kladovo there is a total of 9423 listed people, the total population is 8913, with 486 people abroad; (2) in the settlement of Brza palanka, a total number of listed people is 1613 , in this town there are 855 inhabitants with 746 people abroad; (3) in the village of Vajuga, the total number of listed people was 639, the total population is 422 , with 214 people abroad; (4) in the village of Velesnica, the total number of listed people was 450 , the total population is 215 , with 235 people abroad; (5) in the village of Velika Vrbica a total number of listed people is 1248 , the total population is 836, with 412 people abroad; (6) in the village of Velika Kamenica a total number of listed people is 1211 , the total population is 552, with 658 people abroad; (7) in the village of Grabovica, the total number of listed people is 1460 , the total population is 709 inhabitants with 748 people abroad; (8) in the rural village of Davidovac, the total number of listed people is 552, the total population is 525, while there are 26 people living abroad; (9) in the 
village of Kladušnica, the total number of listed people is 720 , the total population is 631 , with 89 people abroad; (10) in the village of Korbovo, the total number of listed people is 1065 , the total population is 735 , with 330 people living abroad; (11) in the village of Kostol, the total number of listed people is 1101 , the total population is 957 , with 144 people abroad; (12) in the village of Kupuzište, the total number of listed people is 548 , in the village there are 239 inhabitants and 309 people is living abroad; (13) in the village of Ljubičevac, the total number of listed people is 1006, the village has 367 inhabitants, with 639 people abroad; (14) in the village of Mala Vrbica, the total number of listed people is 969 , the total population is 670 , and 299 is living abroad; (15) in the village of Manastirica, the total number of listed people is 213, the total population is 174 , while 39 people is living abroad; (16) in the village of Milutinovac, the total population listed is 209, in the village there are 142 inhabitants, with 66 people abroad; (17) in the village of Novi Sip, the total number of listed people is 783, in the village there are 766 inhabitants and 17 people is living abroad; (18) in Petrovo Selo, the total number of listed people is 84,80 inhabitants live in the village, and there are no people abroad; (19) in the village of Podvrška, the total number of listed people is 1519 , the village has 1003 inhabitants and 516 people are living abroad; (20) in the rural village of Reka, the total number of listed people is 311 , in the village there are 189 inhabitants, with 116 people abroad; (21) in the village of Rečica, the total number of listed people is 29,23 inhabitants live in the village, and 6 people live abroad; (22) in the village of Rtkovo the total number of listed people is 1267 , in the village there are 828 inhabitants and 436 people live abroad; (23) in the settlement of Tekija, the total number of listed people is 807, 804 inhabitants live in the village and 3 people live abroad [9].

Villages with the greatest number of total population (permanent residents who live in the village) in the municipality of Kladovo are Podvrška (1003 inhabitants) and Kostol (957 inhabitants); villages with the lowest total number of inhabitants in this area are Petrovo Selo (80) and Rečica (23 people).

In Kladovo municipality, according to census data (2011), there are villages that have a lower number of the total population than the people living abroad. These are villages: (a) Velika Kamenica - 5 $=52$ inhabitants in the village, 658 people abroad; (b) Velesnica - 215 inhabitants in the village, 235 persons abroad; (c) Grabovica - 709 inhabitants in the village, 748 people abroad; (d) Kupuzište - 239 inhabitants in the village, 309 people abroad; (D) Ljubičevac - 367 inhabitants in the village, 639 people abroad.

\section{Kladovo}

Demographic processes in the municipality of

Data on the population by gender and age in the Municipality of Kladovo according to the Census (2011) show that the total population (20 635) has a greater number of women, 10567 , whereas there are 10068 of men. If we compare the contingent of the population of up to 15 years of age with the contingent of the population of over 65 years of age in this border area, we come to the conclusion that older people are more numerous: 5032 inhabitants are 65 years old and over; 2358 inhabitants are children under 14 years of age. The average age in this border area is 46,8 years: the average age of men is 45,0 years, and the average age of women is 48,5 years [10].

Population in Kladovo region, according to the average age, shows demographic characteristics similar to other parts of Serbia: it entered the stage of old demographic age (average age 40 - 43 years), although it can be talked about the transition to the oldest stage of demographic age (average age $43+$ ). Further process of population aging, characteristic of most developed European and world western regions, characteristic for the second half of the $20^{\text {th }}$ and beginning of the $21^{\text {st }}$ century, characterizes the east borderlands of Serbia. Decline in the proportion of young and increase in the proportion of old population influences the growth of aging index.

Aging is in the entire territory of the Republic conditioned by the tendency of secondary birthrate declining, provided that the differences in the performance of the process at its narrower territorial units are owed to the differential fertility and mortality in specific groups [11], and in the territory of the eastern borderlands also to the strong impact of the so-called external migrations.

The negative consequences of the so-called new demographic mode (negative natural growth, decades-long low fertility, population aging) have long been present in Ključ region and more driven by long-present migration waves. The problem of the population drain of this area, however, has not alerted the local community and the whole society to a kind of «emergency». This problem is not spoken of, and the ways to overcome it are not being searched for. If it has the intent to act systematically on the change of the current demographic situation, the state should determine incentives, population policies in many areas relevant to the reproduction of the population. 
Namely: measures in the system of social care of children, measures for reconciling work and parenting, measures to protect and employ unemployed people, measures of health care for the mother and child, measures in the field of social protection, pension and disability insurance and tax policies, measures in the field of family planning. It seems that it is necessary to apply a differentiated approach in details of the realization of the population policy with regard to the diversity of the demographic situation in the region, such as necessary social support and constant development of the population [12].

\section{Conclusion}

The nature of demographic processes in Serbia leads to the conclusion that the problems of demographic development are complex and dramatic, and their other characteristic is that they are long lasting. The existing model of reproduction and migratory movements of the population is affected by a variety of causes that come from the social, economic and cultural context and requires serious action by government and local government regarding the adoption and implementation of measures of the overall development policy. However, in an effort to meet the preconditions for the realization of the neoliberal projection of socioeconomic development of the Republic in which profit is above all and above everyone - the problem of demographic development is completely marginalized. New political elites, just like those in the near and distant past, do not create a development policy that is appropriate to the seriousness of the demographic problem: strategic objectives in addressing the issue of population (demographic processes and migration) have not been set, thus the solutions, actions and measures for their realization are absent.

\section{References}

1. Bobić M. Demography and Sociology connection or synthesis. Belgrade: Official Gazette, 2007. $254 \mathrm{p}$.

2. Đurđev B. Basic Techniques in Demographics. Novi Sad: Zmaj and the Association of Demographers of Yugoslavia, 2001. $205 \mathrm{p}$.

3. Aritonović I. Serbian Women in Kosovo and Metohija in a War Environment. Priština; Leposavić: Institute of Serbian Culture, 2009. 227 p.

4. Radovanović S., Gigović Lj. Demographic Processes in the Border Region of Serbia towards Bulgaria. Demography, 2010. Vol. VII. Pp. 105-128.

5. Кладово. URL: htpp:// www.tookladovo.rs (date of access: 11.11.2016).

6. Ethnicity by settlement. Belgrade: National Bureau of Statistics, 2011. 122 p.

7. Population, Comparative Population Statistics 1948, 1953, 1961, 1971, 1981, 1991, 2002. Data by settlements, Vol. 9. Belgrade: National Bureau of Statistics, 2004. 219 p.

8. Nikitović V.(ed.). The population of Serbia at the beginning of the 21st century. Belgrade, 2014. 295 c. URL:http://webrzs.stat.gov.rs/WebSite/repository/docume nts/00/01/86/05/POPULACIJA_SRBIJE_POCETKOM_2 1_VEKA.pdf (date of access: 11.11 .2016 ).

9. Census of Population, Households and Dwellings in the Republic of Serbia, first results. Belgrade: Republic Institute for Statistics, 2011. 610 p.

10. Population, Gender and Age, Data on Settlements, Vol. 2. Belgrade: Republic Institute for Statistics, 2012. 610 p.

11. Vojković G., Devedžić M., Penev G. Serbia among Demographically Oldest Countries. Our Themes, 2006. № 1. Pp. 40-51.

12. Gavrilović A., Rašević M. Restoration of the Serbian Population and Population Policy of the State and Local Governments. Belgrade: Official Gazette, 1999. 149 p.

Vesna S. Trifunovic, Doctor of sociological sciences, associate professor, University of Kragujevac.

Трифунович Весна Светислава, доктор социологических наук доцент факультета педагогических наук Университета г. Крагуевац. 